\title{
Changes in the urinary excretion of acid-soluble peptides in rats injected with streptozotocin or dexamethasone: a trial to estimate the changes in the rate of whole-body protein degradation in those rats
}

\author{
BY TAEK JEONG NAM, TADASHI NOGUCHI* AND HIROSHI NAITO \\ Department of Agricultural Chemistry, Faculty of Agriculture, University of Tokyo, Bunkyo-ku, \\ Tokyo 113, Japan
}

(Received 2 June 1989-Accepted 15 June 1990)

\begin{abstract}
Urinary excretion of acid-soluble peptides (ASP) was measured in rats given streptozotocin or dexamethasone. Streptozotocin-induced diabetic rats excreted increased amounts of urinary nitrogen and ASP-form amino acids. The urinary ratio for N: ASP-form leucine plus valine, which has been shown to reflect the efficiency of dietary $\mathrm{N}$ utilization, increased in the diabetic rats, suggesting the impaired utilization of dietary $\mathbf{N}$ (and re-utilization of endogenous $\mathbf{N}$ ). Dexamethasone administration to adrenalectomized rats caused increased excretion of urinary ASP-form leucine plus valine with a concomitant increase in $\mathrm{N}$ excretion. However, urinary ratio for $\mathrm{N}$ : ASP-form leucine plus valine did not change significantly. The results suggested that dexamethasone caused increased degradation of body proteins, but maintained the efficiency of dietary $\mathbf{N}$ utilization or re-utilization of endogenous $\mathbf{N}$. Based on the present observations and the hypothesis proposed previously by the present authors (Noguchi et al. 1988) that urinary excretion of ASP-form leucine plus valine reflects the rate of whole-body protein degradation and the urinary ratio for N: ASP-form leucine plus valine represents $\mathrm{N}$ utilization, the origin of urinary $\mathbf{N}$ in streptozotocin-diabetic and dexamethasone-administered rats is discussed.
\end{abstract}

Urinary acid-soluble peptides: Diabetes: Dexamethasone: Protein degradation: Rat

Insulin has been presumed to be a most important hormone which regulates the utilization of dietary proteins (Munro, 1964; Manchester, 1970; Waterlow et al. 1978). When rats are injected with streptozotocin or alloxan and diabetes is induced, the rats lose their body proteins and the urinary excretion of nitrogen greatly increases. Several authors tried to estimate the protein synthesis and degradation rate in experimentally induced diabetic rats (Pain \& Garlick, 1974; Millward et al. 1976; Millward \& Waterlow, 1978; Waterlow et al. 1978; Flaim et al. 1980; Pain et al. 1983; Garlick et al. 1985). The results showed that protein synthetic rate in muscle decreases and protein degradation rate increases in experimentally-induced diabetic animals.

Glucocorticoids have been proven to affect the synthesis and degradation rate of body proteins (Millward et al. 1976; Nishizawa et al. 1978; Waterlow et al. 1978; Tomas et al. 1979, 1984; Odedra \& Millward, 1982; Odedra et al. 1983). Particularly, glucocorticoids are known to accelerate the degradation rate of body proteins.

In our previous experiments, we suggested that the rate of urinary excretion of acidsoluble peptides (ASP) is possibly a useful index for the evaluation of whole-body protein degradation (Noguchi et al. 1982, 1988). The excretion rate was proportional to metabolic body size in women and rats (Noguchi et al. 1982). Furthermore, the urinary N:ASP ratio correlates with the efficiency of utilization of dietary $N$ (Noguchi et al. 1988). From these observations, we presumed that if we measure the urinary excretion of $\mathrm{N}$ and ASP in

\footnotetext{
* For reprints.
} 
experimentally-induced diabetic rats or glucocorticoid-injected rats, we would possibly be able to estimate the changes in protein degradation rate (and synthesis rate) in those rats. The present paper reports the results.

\section{MATERIALS AND METHODS}

Streptozotocin-induced diabetes

Male Wistar rats with an initial body-weight of approximately $150 \mathrm{~g}$ were purchased from Shizuoka Agricultural Cooperative for Laboratory Animals (Hamamatsu, Japan). They were fed on a casein diet ( $120 \mathrm{~g}$ casein $/ \mathrm{kg}$ diet) and water ad lib. for $5 \mathrm{~d}$. At this time, two groups of rats were injected with $50 \mathrm{mg}$ streptozotocin (dissolved in $50 \mathrm{~mm}$-citrate buffer $(\mathrm{pH} 4.5$ ) at a concentration of $33 \mathrm{mg} / \mathrm{ml}) / \mathrm{kg}$ body-weight intraperitoneally. The other two groups of rats were injected with buffer only. From day 5, two groups of the rats (one group streptozotocin-injected and the other not injected) were fed on the casein diet and the other two groups of rats were fed on a protein-free diet. The number of rats in each group is shown in Table 1. The casein diet contained the following ingredients $(\mathrm{g} / \mathrm{kg}$ diet): casein 120 , maize oil 50 , vitamin mixture 10 , mineral mixture 40 , cellulose powder 50 , L-methionine 2, and $\beta$-maize starch 728. Vitamin and mineral mixtures were obtained from Oriental Yeast Co. (Tokyo). These mixtures were prepared according to Rogers \& Harper (1965). The protein-free diet was prepared by replacing casein and methionine in the casein diet by $\beta$-maize starch.

\section{Adrenalectomized rats}

Rats were similar to those used in the experiment on streptozotocin-induced diabetes (control rats, i.e. not operated on and given the casein diet, were the same). The number of rats in each group is shown in Table 4. They were fed on the casein diet and water ad lib. for $4 \mathrm{~d}$ after which bilateral adrenalectomy was performed. Sham-operated rats were also prepared. One group of rats were injected with dexamethasone $(1 \mathrm{mg} / \mathrm{kg}$ body-weight daily) subcutaneously. Dexamethasone was suspended in maize oil. Control rats were injected with maize oil only. After the operation and the first injection, rats received the casein diet and water ad lib. This time, the water contained $5 \mathrm{~g}$ sodium chloride/ 1.

\section{Collection and analysis of urine}

After the injection of dexamethasone or streptozotocin, urine samples were collected every $24 \mathrm{~h}$ in a bottle containing $5 \mathrm{ml}$ of sulphosalicylic acid $(100 \mathrm{~g} / 1)$. The urine samples were stored at $-20^{\circ}$ until they were analysed.

If the volume of urine collected was less than $25 \mathrm{ml}$, water was added to make the volume up to $25 \mathrm{ml}$. If the volume was in excess of $25 \mathrm{ml}$, the volume was measured. A portion of each of the samples was retained for $\mathrm{N}$ determination. The other portion was filtered through Whatman no. 44 paper. ASP in the filtered urine was determined as reported previously (Noguchi et al. 1988). Urinary $\mathrm{N}$ was determined by the micro-Kjeldahl method. The average values during days $1-4$ (early stage of experiment) and days 5-7 (late stage of experiment) or in some cases (e.g. for control rats the values of which are presumed not to change significantly as a function of the stage of the experiment) representative values during the experimental period were employed for the analyses of the results.

\section{Statistical analyses}

The results were analysed employing split-plot analysis (Snedecor \& Cochran, 1967a), taking the variation between animal stratum (the effect of streptozotocin and diet, or the effect of adrenalectomy) as the main plot stratum and the variation within animal stratum (the effect of stage of experiment) as the sub plot stratum. The split-plot analysis is appropriate in this case as there are only two stages involved. For the analysis of the results, 
five randomly selected observations for each treatment were employed in order to simplify the analysis. When the effect of treatment itself was not significant and the interaction between treatment $\times$ stage of experiment was significant, two-way classification (analysis of variance) (Snedecor \& Cochran, 1967 b, for the experiment of diabetes) was applied for each stage of the experiment. The difference among the means of the groups in the experiment of adrenalectomy was analysed by Tukey's Q test (Snedecor \& Cochran, $1967 c$ ).

\section{RESULTS}

Table 1 shows the body-weight changes in the two groups of rats given streptozotocin and the two groups of control rats (only the solute of streptozotocin was injected). Injection of streptozotocin caused a loss in body-weight. Blood sugar concentrations $7 \mathrm{~d}$ after streptozotocin injection were 1.49 (SE 0.17), 1.37 (SE 0.06), 4.31 (SE 0.41), and 6.85 (SE 1.23$) \mathrm{g} / 1$, respectively for the control rats fed on the casein diet, the control rats fed on the protein-free diet, the streptozotocin-injected rats fed on the casein diet, and the streptozotocin-injected rats fed on the protein-free diet. The streptozotocin-injected rats showed typical diabetic symptoms and will be referred to as diabetic rats. Because the treatments caused changes in appetite some of the observations may be related, in part at least, to intake differences, but these cannot be resolved at present.

Table 2 shows changes in the excretion of ASP-form amino acids in diabetic and control rats; levels of ASP-form amino acids are expressed as the amount of ASP-form leucine plus valine as discussed previously (Noguchi et al. 1988). Streptozotocin injection caused an increase in the excretion of ASP-form leucine plus valine. This suggested increased degradation of body proteins in the diabetic rats. Dietary treatment also affected the rate of excretion of ASP-form leucine plus valine. This is consistent with previous observations (Noguchi et al. 1988). Diabetes induced acceleration of body protein degradation even in the protein-depleted rats (comparison between protein-depleted normal rats and proteindepleted diabetic rats), suggesting that streptozotocin treatment also causes enhanced body protein degradation under protein-deprived conditions. These and other conclusions described in following sections are valid only when our hypothesis (urinary excretion of ASP is proportional to the rate of whole-body protein degradation) holds true under any nutritional or physiological conditions. It should be emphasized that the assumption is unproven and further studies, for example on the dietary or hormonal factors affecting the rate of re-utilization of ASP, need to be conducted.

Table 2 shows changes in the urinary ratio for $\mathrm{N}$ :ASP-form leucine plus valine in diabetic and normal rats fed on the casein or protein-free diets. As was suggested in our previous paper (Noguchi et al. 1988), the ratio N:ASP-form leucine plus valine possibly shows the efficiency of $\mathrm{N}$ utilization in the body. The high value for $\mathrm{N}$ : ASP-form leucine plus valine in diabetic rats fed on the casein diet or protein-free diet means that dietary $\mathrm{N}$ and $\mathrm{N}$ (or amino acids) released by tissue protein degradation are wasted extensively in these rats. In contrast, normal rats fed on the casein or protein-free diets showed low $\mathrm{N}$ : ASP-form lcucine plus valine values, suggesting efficient re-utilization of tissue $\mathrm{N}$ and utilization of dietary $\mathrm{N}$ in these rats.

Table 3 shows an increase in ASP-form proline excretion. If this increase reflects enhanced degradation of collagen, then both diet and streptozotocin administration could cause accelerated degradation of collagen.

Although excretion of ASP-form amino acids increased in the diabetic rats, the amino acid pattern of ASP did not change significantly (results not shown). These findings are consistent with those reported previously (Noguchi et al. 1982), although the method to determine ASP-form amino acids was different.

Table 3 shows changes in urinary excretion of $N^{\tau}$-methylhistidine $(3 \mathrm{MH})$ in diabetic and 
Table 1. Body-weights and food intakes of streptozotocin-injected or vehicle-injected rats fed on a casein or a protein-free diet

(Mean values for each group of rats; no. of rats in parentheses)

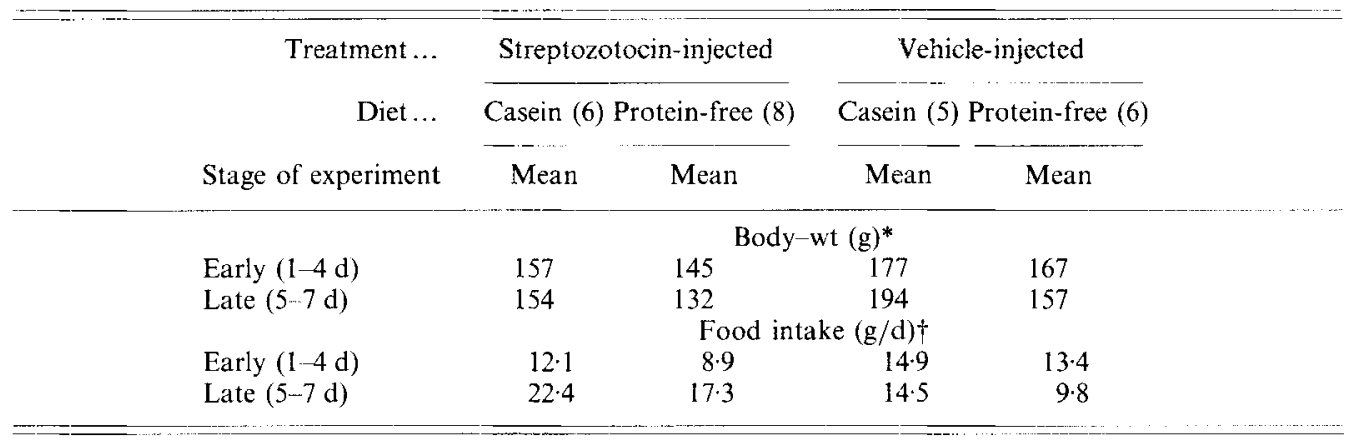

NS, not significant.

* Effect of: streptozotocin (S), $P<0.01$; diet (D), $P<0.01$; stage of experiment (T), $P<0.01 ; S \times D, N S$; $\mathrm{S} \times \mathrm{T}, P<0.01 ; \mathrm{D} \times \mathrm{T}, P<0.01 ; \mathrm{S} \times \mathrm{D} \times \mathrm{T}, P<0.01 ;$ by split-plot analysis (Snedecor \& Cochran, $1967 a$ ). For early stage; $\mathrm{S} \times \mathrm{D}$, NS; for late stage, $\mathrm{S} \times \mathrm{D}, P<0.05$ (Snedecor \& Cochran, $1967 b$ ). Residual mean square for the between-animal stratum $=51.0$ on $16 \mathrm{df}$; residual mean square for the within-animal stratum $=5.3$ on $16 \mathrm{df}$.

$\dagger$ Effect of: streptozotocin (S), NS; diet (D), $P<0.05$; stage of experiment (T), $P<0.01 ; \mathrm{S} \times \mathrm{D}, \mathrm{NS} ; \mathrm{S} \times \mathrm{T}$, $P<0.01 ; \mathrm{D} \times \mathrm{T}, P<0.05 ; \mathrm{S} \times \mathrm{D} \times \mathrm{T}$, NS, by split-plot analysis (Snedecor \& Cochran, $1967 a$ ). For early stage, effect of S, $P<0.01$, the mean value increased; for late stage, the effect of $\mathrm{S}, P<0.01$, the mean value decreased (Snedecor \& Cochran, $1967 \mathrm{~b}$ ). Residual mean square for the between-animal stratum $=17 \cdot 1$ on $16 \mathrm{df}$; residual mean square for the within-animal stratum $=3 \cdot 1$ on $16 \mathrm{~d} f$.

Table 2. Urinary acid-soluble peptide (ASP)-form leucine plus valine excretion and $N: A S P$ form leucine plus valine ratio in streptozotocin-injected or vehicle-injected rats fed on a casein or a protein-free diet

(Mean values for each group of rats)

\begin{tabular}{|c|c|c|c|c|}
\hline \multirow{2}{*}{$\begin{array}{r}\text { Treatment ... } \\
\text { Diet... }\end{array}$} & \multicolumn{2}{|c|}{ Streptozotocin-injected } & \multicolumn{2}{|c|}{ Vehicle-injected } \\
\hline & Casein & Protein-free & Casein & Protein-free \\
\hline Stage of experiment & Mean & Mean & Mean & Mean \\
\hline \multicolumn{5}{|c|}{ Urinary ASP-form leucine plus valine excretion $(\mu \mathrm{mol} / \mathrm{d}$} \\
\hline \multirow{3}{*}{$\begin{array}{l}\text { Early }(1-4 d) \\
\text { Late }(5-7 d)\end{array}$} & 3.80 & \multirow{2}{*}{$\begin{array}{r}2.79 \\
2.41\end{array}$} & 2.67 & 1.54 \\
\hline & 4.95 & & 288 & $1 \cdot 26$ \\
\hline & \multicolumn{4}{|c|}{ Urinary $\mathrm{N}$ :ASP-form leucine plus valine $(\mathrm{mg} / \mu \mathrm{mol}) \dagger$} \\
\hline Early $(1-4 d)$ & $36 \cdot 4$ & $39 \cdot 4$ & $25 \cdot 2$ & $20 \cdot 8$ \\
\hline Late $(5-7 \mathrm{~d})$ & $64 \cdot 4$ & $38 \cdot 1$ & $21 \cdot 8$ & $19 \cdot 8$ \\
\hline
\end{tabular}

NS, not significant.

* Effect of: streptozotocin (S), $P<0.01$; diet (D), $P<0.01$; stage of experiment (T), $P<0.05 ; \mathrm{S} \times \mathrm{D}, \mathrm{NS}$; $\mathrm{S} \times \mathrm{T}, P<0.01 ; \mathrm{D} \times \mathrm{T}, P<0.01 ; \mathrm{S} \times \mathrm{D} \times \mathrm{T}, P<0.01$, by split-plot analysis (Snedecor \& Cochran, 1967a). For early stage, $\mathrm{S} \times \mathrm{D}$, NS; for late stage, $\mathrm{S} \times \mathrm{D}, P<0 \cdot 01$. Residual mean square for the between-animal stratum $=0.19$ on $16 \mathrm{df}$; residual mean square for the within-animal stratum $=0.070$ on $16 \mathrm{df}$.

$\dagger$ Effect of: streptozotocin (S), $P<0.01$; diet (D), $P<0.01$; stage of experiment (T), $P<0.01 ; \mathrm{S} \times \mathrm{D}, \mathrm{NS}$; $\mathrm{S} \times \mathrm{T}, P<0.01 ; \mathrm{D} \times \mathrm{T}, P<0.0 \mathrm{I} ; \mathrm{S} \times \mathrm{D} \times \mathrm{T}, P<0.01$; by split-plot analysis (Snedecor \& Cochran, $1967 a$ ). For early stage, $\mathrm{S} \times \mathrm{D}, P<0.01$; for late stage, $\mathrm{S} \times \mathrm{D}, P<0.01$ (Snedecor \& Cochran, $1967 \mathrm{~b}$ ). Residual mean square for the between-animal stratum $=33.9$ on $16 \mathrm{df}$; residual mean square for the within-animal stratum $=29.8$ on $16 \mathrm{df}$. 
Table 3. Urinary acid-soluble peptide (ASP)-form proline excretion and $N^{\top}$-methylhistidine excretion in streptozotocin-injected or vehicle-injected rats fed on a casein or a protein-free diet

(Mean values for each group)

\begin{tabular}{|c|c|c|c|c|}
\hline \multirow{2}{*}{$\begin{array}{r}\text { Treatment ... } \\
\text { Diet ... }\end{array}$} & \multicolumn{2}{|c|}{ Streptozotocin-injected } & \multicolumn{2}{|c|}{ Vehicle-injected } \\
\hline & Casein & Protein-free & Casein & Protein-free \\
\hline \multirow[t]{2}{*}{ Stage of experiment } & Mean & Mean & Mean & Mean \\
\hline & \multicolumn{4}{|c|}{ Urinary ASP-form proline excretion $(\mu \mathrm{mol} / \mathrm{d})^{*}$} \\
\hline \multirow{3}{*}{$\begin{array}{l}\text { Early }(1-4 d) \\
\text { Late }(5-7 d)\end{array}$} & $6 \cdot 52$ & $6 \cdot 24$ & 5.94 & 4.00 \\
\hline & $9 \cdot 55$ & $5 \cdot 29$ & $5 \cdot 80$ & $3 \cdot 50$ \\
\hline & \multicolumn{4}{|c|}{ Urinary $\mathrm{N}^{\tau}$-methylhistidine excretion $(\mathrm{mg} / \mu \mathrm{mol}) \dagger$} \\
\hline Early $(1.4 \mathrm{~d})$ & 1.93 & $2 \cdot 19$ & $1 \cdot 22$ & 1.21 \\
\hline Late $(5-7 \mathrm{~d})$ & 1.79 & 1.86 & $1 \cdot 26$ & 1.22 \\
\hline
\end{tabular}

NS, not significant.

* Effect of: streptozotocin (S), $P<0.01$; diet (D), $P<0.01$; stage of experiment (T), $P<0.05 ; \mathrm{S} \times \mathrm{D}, \mathrm{NS}$; $\mathrm{S} \times \mathrm{T}, P<0.01 ; \mathrm{D} \times \mathrm{T}, P<0.01 ; \mathrm{S} \times \mathrm{D} \times \mathrm{T}, P<0.01$, by split-plot analysis (Snedecor \& Cochran, $1967 a$ ) For early stage, $\mathrm{S} \times \mathrm{D}, P<0.01$; for late stage, $\mathrm{S} \times \mathrm{D}, P<0.05$ (Snedecor \& Cochran, 1967b). Residual mean square for the between-animal stratum $=1.07$ on $16 \mathrm{df}$; residual mean square for the within-animal stratum $=0.27$ on $16 \mathrm{df}$.

$\ddagger$ Effect of: streptozotocin (S), $P<0.01$; diet (D), NS; stage of experiment (T), $P<0.05 ; \mathrm{S} \times \mathrm{D}, \mathrm{NS} ; \mathrm{S} \times \mathrm{T}$, $P<0.05 ; \mathrm{D} \times \mathrm{T}, \mathrm{NS} ; \mathrm{S} \times \mathrm{D} \times \mathrm{T}, \mathrm{NS}$, by split-plot analysis (Snedecor \& Cochran, $1967 \mathrm{a}$ ). Residual mean square for the between-animal stratum $=0.04$ on $16 \mathrm{df}$; residual mean square for the within-animal stratum $=0.02$ on $16 \mathrm{df}$.

control rats. Streptozotocin injection significantly affected the urinary excretion of $3 \mathrm{MH}$ whereas diet did not. The increased excretion of $3 \mathrm{MH}$ in the diabetic rats is consistent with our previous observations (Nagasawa et al. 1982; Noguchi et al. 1982). In our previous paper (Noguchi et al. 1988), we suggested that in many instances urinary excretion of ASPform amino acids correlates with that of $3 \mathrm{MH}$, but in other instances it does not. From those observations we implied that ASP-form amino acids and $3 \mathrm{MH}$ are different indices; the former may be the index of whole-body protein breakdown and the latter that of muscle protein degradation. The results shown in Tables 2 and 3 show that the two indices do not reflect the same physiological events (see the effect of diet).

Table 4 shows the food intake of adrenalectomized or control rats with or without dexamethasone. Adrenalectomy affected food intake significantly. However, rats recovered partially from the effect after 5-7 d. Because treatment and stage of experiment significantly affected the food intake, subsequent effects of treatment or stage of experiment may be influenced by the secondary effect of food intake.

Table 4 shows changes in body-weight of rats given dexamethasone. Administration of dexamethasone (in maize oil) to adrenalectomized rats caused severe body-weight loss. This was more marked at the later stage of the experiment. Unexpectedly, maize oil alone prevented the body-weight loss partially. The reason for this phenomenon cannot be explained at present.

Table 5 shows the changes in urinary excretion of ASP-form leucine plus valine in the adrenalectomized or sham-operated rats given dexamethasone (in maize oil) or maize oil alone. Administration of dexamethasone enhanced the excretion of ASP-form leucine plus valine suggesting increased body protein degradation in those rats. Although dexame- 
Table 4. Effect of adrenalectomy (Adx) and administration of dexamethasone (Dex) on food intakes and body-weights of rats

(Mean values for each group; no. of rats in parentheses)

\begin{tabular}{|c|c|c|c|c|c|c|}
\hline \multirow{2}{*}{$\begin{array}{l}\text { Treatment... } \\
\text { Stage of experi- } \\
\text { ment }\end{array}$} & \multirow{2}{*}{$\frac{\text { Normal (5) }}{\text { Mean }}$} & \multirow{2}{*}{$\frac{\text { Adx (7) }}{\text { Mean }}$} & \multirow{2}{*}{$\frac{\operatorname{Adx}+\operatorname{Dex}(6)}{\text { Mean }}$} & \multirow{2}{*}{$\frac{\mathrm{Adx}+\text { maize oil }(6)}{\text { Mein }}$} & \multicolumn{2}{|l|}{ Adx sham-op. (7) } \\
\hline & & & & & Mean & LSD $^{*}$ \\
\hline & \multicolumn{6}{|c|}{ Food intake $(\mathrm{g} / \mathrm{d}) \dagger$} \\
\hline Early $(1-4 d)$ & $14 \cdot 9^{\circ}$ & $3 \cdot 2^{\mathrm{a}}$ & $6 \cdot 2^{a b}$ & $6 \cdot 9^{\mathrm{b}}$ & $8 \cdot 6^{13}$ & $3-3$ \\
\hline \multirow[t]{2}{*}{ Late $(5-7 \mathrm{~d})$} & $14 \cdot 5^{\gamma}$ & $8 \cdot 0^{\alpha}$ & $9 \cdot 0^{x / 3}$ & $10 \cdot 8^{x \beta \gamma}$ & $12 \cdot 5^{\beta \gamma}$ & $4 \cdot 0$ \\
\hline & \multicolumn{6}{|c|}{ Body-wt (g)t } \\
\hline Early $(1-4 d)$ & $177^{\circ}$ & $160^{\mathrm{an}}$ & $157^{\mathrm{a}}$ & $175^{\circ}$ & $169^{\mathrm{bc}}$ & 9.9 \\
\hline Late $(5-7 d)$ & $194^{\circ}$ & $156^{\beta}$ & $134^{\alpha}$ & $180^{\gamma}$ & $183^{\gamma \delta}$ & $13 \cdot 3$ \\
\hline
\end{tabular}

NS, not significant

* Least significant difference at 5\% calculated using Tukey's $Q$ test appropriate only for comparison of treatments within each row.

$\dagger$ Effect of: treatment (TM), $P<0.01$; stage of experiment (T), $P<0.01 ; \mathrm{T} \times \mathrm{TM}, P<0.01$, by split-plot analysis (Snedecor \& Cochran, 1967a). The difference between the treatments in each stage was analysed by Tukey's Q test (Snedecor \& Cochran, 1967c). The values with unlike superscript letters were significantly difierent $(P<0.05$ or less $)$.

$\$$ Effect of : treatment (TM) $P<0.01$; stage of experiment (T), NS; TM $\times$ T, $P<0.01$, by split-plot analysis (Snedecor \& Cochran, 1967 a). The difference between the treatments in each stage was analysed by Tukey's $Q$ test (Snedecor \& Cochran, $1967 \mathrm{c})$. The values with unlike superscript letters were significantly different $(P<0.05$ or less).

thasone-injected rats showed increased excretion of ASP-form leucine plus valine (almost fourfold), the urinary ratio for N: ASP-form leucine plus valine did not change significantly (Table 5). This finding indicates that the increase in ASP-form leucine plus valine excretion was accompanied by raised $\mathrm{N}$ excretion and suggests that the utilization of dietary and endogenous $\mathrm{N}$ is not significantly affected in dexamethasone-injected adrenalectomized rats (we suggested in the previous paper that $\mathrm{N}$ : ASP-form leucine plus valine possibly reflects the efficiency of $\mathrm{N}$ utilization, Noguchi et al. 1988). That is, although dexamethasone caused increased body protein degradation it possibly maintained the efficiency of reutilization of endogenous $\mathrm{N}$ (or amino acids) because if re-utilization is impaired N:ASPform leucine plus valine will change significantly, as in the case of streptozotocin-injected rats. This implies that glucocorticoids play an important role in assimilation of dietary $\mathrm{N}$ or in re-utilization of $\mathrm{N}$ (or amino acids) released by the degradation of tissue proteins. The increased urinary N:ASP-form leucine plus valine during the early stage of the experiment in the adrenalectomized rats not given dexamethasone favours this assumption. In these rats impaired utilization of dietary $\mathrm{N}$ or re-utilization of endogenously produced $\mathrm{N}$ (or amino acids) during $1-4 \mathrm{~d}$ after adrenalectomy is assumed.

Table 5 shows increased excretion of $3 \mathrm{MH}$ in sham-operated or adrenalectomized rats given dexamethasone or maize oil alone. As is evident from Table 5, adrenalectomy itself enhanced the excretion of $3 \mathrm{MH}$ and dexamethasone accelerated it. As mentioned previously (p. 41) there is a difference in the physiological significance of the excretion of ASP-form leucine plus valine and that of $3 \mathrm{MH}$; the explanation is also applicable to the results in Table 5. The excretion of ASP-form leucine plus valine usually correlates with that of $3 \mathrm{MH}$, but, in some cases, it does not. In the present case, $3 \mathrm{MH}$ excretion was affected by adrenalectomy more extensively than ASP-form leucine plus valine excretion. However, the effect of dexamethasone administration brought about a more marked increase in ASP-form leucine plus valine excretion than in $3 \mathrm{MH}$ excretion. An enhanced 
Tablc 5. Effect of adrenalectomy ( $A d x)$ and administration of dexamethasone (Dex) on urinary excretion of acid-soluble peptide form-leucine plus valine $(A S P-L e u+V a l)$ and $N^{\top}$ methylhistidine and urinary $N: A S P-L e u+V a l$ ratio

(Mean values for each group of rats)

\begin{tabular}{|c|c|c|c|c|c|c|}
\hline Treatment ... & Normal & Adx & Adx + Dex & Adx + vehicle & Adx sham-op. & \\
\hline \multirow[t]{2}{*}{$\begin{array}{l}\text { Stage of experi- } \\
\text { ment }\end{array}$} & Mean & Mean & Mean & Mean & Mean & $\mathrm{LSD}^{*}$ \\
\hline & \multicolumn{6}{|c|}{ Urinary excretion of ASP-Leu $+\mathrm{Val}(\mu \mathrm{mol} / \mathrm{d}) \dagger$} \\
\hline Early $(1-4 d)$ & $2 \cdot 67^{a}$ & $3 \cdot 10^{\mathrm{a}}$ & $5 \cdot 90^{\mathrm{b}}$ & $3 \cdot 28^{\mathrm{u}}$ & $2 \cdot 51^{\mathrm{a}}$ & $1 \cdot 51$ \\
\hline Late $(5-7 \mathrm{~d})$ & $2 \cdot 88^{\circ}$ & $2 \cdot 48^{x}$ & $9 \cdot 19^{/}$ & $2 \cdot 78^{\alpha}$ & $2 \cdot 70^{\alpha}$ & $3 \cdot 15$ \\
\hline $\begin{array}{l}\text { Early }(1-4 d) \\
\text { Late }(5-7 d)\end{array}$ & $\begin{array}{l}25 \cdot 2^{a b} \\
21 \cdot 8^{a}\end{array}$ & $\begin{array}{l}32 \cdot 1^{\mathrm{b}} \\
25 \cdot 4^{\alpha}\end{array}$ & $\begin{array}{c}\text { Urinary N:A } \\
25 \cdot 4^{\text {ab }} \\
23 \cdot 2^{\alpha}\end{array}$ & $\begin{array}{c}\mathrm{u}+\mathrm{Val}(\mathrm{mg} / \mu \mathrm{m} \\
19 \cdot 3^{\mathrm{a}} \\
21 \cdot 7^{\alpha}\end{array}$ & $\begin{array}{l}22 \cdot 7^{\mathrm{ab}} \\
20 \cdot 0^{x}\end{array}$ & $\begin{array}{r}11 \cdot 8 \\
6.9\end{array}$ \\
\hline & \multicolumn{6}{|c|}{$N^{\top}$-Methylhistidine excretion $(\mu \mathrm{mol} / \mathrm{d}) \S$} \\
\hline Early $(1-4 d)$ & $1 \cdot 22^{\mathrm{a}}$ & $2 \cdot 07^{\mathrm{b}}$ & $2 \cdot 64^{c}$ & $2 \cdot 17^{\mathrm{b}}$ & $1 \cdot 38^{\mathrm{a}}$ & $0 \cdot 31$ \\
\hline Late $(5-7 d)$ & $1 \cdot 26^{x}$ & $1 \cdot 61^{\beta}$ & $2 \cdot 25^{\gamma}$ & $1-90^{\beta}$ & $1.08^{\alpha}$ & $0 \cdot 30$ \\
\hline
\end{tabular}

\footnotetext{
NS, not significant

* Least significant difference at $5 \%$ calculated using Tukey's $Q$ test appropriate only for comparison of treatments within each row.

$\uparrow$ Effect of: treatment (TM), $P<0.01$; stage of experiment (T), $P<0.05 ; \mathrm{TM} \times \mathrm{T}, P<0.01$, by split-plot analysis (Snedecor \& Cochran, 1967a). The difference between the treatments in each term was analysed by Tukey's Q test (Snedecor \& Cochran, 1967c). The values with unlike superscript letters were significantly different $(P<0.05$ or less).

$\$$ Effect of: treatment (TM) $P<0.01$; stage of experiment (T), $P<0.05$; TM $\times$ T, NS, by split-plot analysis (Snedccor \& Cochran, $1967 \mathrm{a}$ ). The difference between the treatments in each term was analysed by Tukey's $Q$ test (Snedecor \& Cochran, $1967 \mathrm{c})$. The values with unlike superscript letters were significantly different $(P<0.05$ or less).

$\S$ Effect of: treatment (TM) $P<0.01$; stage of experiment (T), $P<0.01 ; \mathrm{TM} \times \mathrm{T}, P<0.01$, by split-plot analysis (Snedecor \& Cochran, 1967a). The difference between the treatments in each term was analysed by Tukey's Q test (Snedecor \& Cochran, 1967c). The values with unlike superseript letters were significantly different $(P<0 \cdot 05$ or less $)$.
}

excretion of $3 \mathrm{MH}$ after glucocorticoid administration has also been reported by Nishizawa et al. (1978) and Tomas et al. (1979).

\section{DISCUSSION}

The method of assessment of the status of protein metabolism from the urinary excretion of ASP-form amino acids (Noguchi et al. 1988) was applied to assess the status of protein metabolism in diabetic and dexamethasone-injected rats. In a previous paper, we suggested that urinary excretion of ASP-form amino acids could reflect the rate of whole-body protein degradation and the urinary ratio for $\mathrm{N}$ : ASP-form amino acids correlates with the efficiency of utilization of $\mathrm{N}$ sources (Noguchi et al. 1988). In the present investigations, evidence supporting the previously mentioned assumptions was obtained. If our hypothesis is valid, the results show that: (1) whole-body protein degradation increases in acute experimental diabetes; (2) the efficiency of utilization of dietary $N$ and re-utilization of tissue $\mathrm{N}$ is impaired in the diabetic rats, probably because insulin deficiency causes impaired body protein synthesis; (3) administration of dexamethasone augments whole-body protein degradation, however; (4) dexamethasone does not bring about impaired $\mathrm{N}$ utilization. These conclusions are all consistent with assumptions proposed by earlier workers (Pain \& Garlick, 1974; Millward et al. 1976; Nishizawa et al. 1978; Tomas et al. 
1979; Flaim et al. 1980; Odedra \& Millward, 1982; Odedra et al. 1983; Pain et al. 1983; Tomas et al. 1984; Garlick et al. 1985). This confirmation favours our previous hypothesis that the method involving measurement of urinary excretion of ASP-form amino acids is useful in assessment of the status of protein metabolism in man and animals (Noguchi et al. 1988).

By extending the previous hypothesis, we tried to evaluate quantitatively the status of protein metabolism in diabetic and dexamethasone-injected rats. For this estimation, the following assumptions were made based on previous observations: (1) urinary $\mathrm{N}$ excretion of normal rats fed on the protein-free diet equals endogenous $N$ excretion; (2) endogenous $\mathrm{N}$ excretion of the other groups of rats is proportional to the urinary ASP-form leucine plus valine excretion, i.e. N : ASP-form leucine plus valine is constant for such losses; (3) urinary excretion of $\mathrm{N}$ in normal rats fed on the casein diet comprises non-utilized exogenous (or dietary) $\mathrm{N}$ and $\mathrm{N}$ which is produced by tissue protein breakdown and not re-utilized for tissue protein synthesis; and (4) since total urinary $\mathrm{N}$ excretion of diabetic rats fed on the protein-free diet was more than that of endogenous $\mathrm{N}$ calculated from the excretion of ASP-form leucine plus valine excretion on assumption 2, the difference between the total $\mathrm{N}$ excretion and endogenous $\mathrm{N}$ excretion was assumed to be the extra $\mathrm{N}$ excretion. This extra $\mathrm{N}$ excretion was assumed to be caused by the increased production of endogenous $\mathrm{N}$ because of impaired protein synthesis (i.e. impaired re-utilization of amino acids derived from degradation of body proteins) in the absence of sufficient insulin in the diabetic rats. Furthermore, the extra $\mathrm{N}$ excretion in casein-fed diabetic rats was calculated as (endogenous $N$ in casein-fed diabetic rats $\div$ endogenous $N$ in diabetic rats fed on the protein-free diet) $\times$ extra $N$ excreted in the diabetic rats fed on the protein-free diet.

Dietary $\mathrm{N}$ intake, urinary $\mathrm{N}$ and ASP-form leucine plus valine excretions were calculated as means or representative values in the case of control rats (in the latter, values were presumed not to change significantly) observed after day 5 (the late stage of the experiment).

Table 6 shows the values obtained from these calculations. The results clearly show impaired utilization of dietary $\mathrm{N}$ and impaired re-utilization of endogenous $\mathrm{N}$ in diabetic rats fed on the casein diet. At the same time, the values indicate how much the degradation rate of body proteins is increased in diabetic rats. An increase in the rate of protein degradation was also observed in dexamethasone-injected rats. Since the protein-free diet was not fed to dexamethasone-injected rats, exact calculation of extra $\mathrm{N}$ excretion in dexamethasone-injected rats was impossible. The extra $\mathrm{N}$ excretion was, therefore, included in the exogenous $\mathrm{N}$ (excretion) in the dexamethasone-injected rats. However, extra $\mathrm{N}$ excretion must be small in those rats, since exogenous $\mathrm{N}$ excretion itself was small (i.e. total urinary $\mathrm{N}$ excretion is close to endogenous $\mathrm{N}$ excretion).

These calculations are based on many assumptions, as discussed previously. Therefore, the present conclusions should be considered to be tentative but it appears that the conclusions may provide valuable information for the clinical and nutritional assessment of protein metabolism in diabetic and glucocorticoid-administered patients.

Further trials to calculate the indices by different methods of assessment of protein metabolism will give information on the validity of the method proposed in the present paper.

The physiological significance of ASP-form leucine plus valine excretion has been discussed extensively in a previous paper (Noguchi et al. 1988). There are many problems to be solved in the future concerning the physiological events which cause urinary excretion of ASP-form leucine plus valine. However, available findings suggest that measurement of both the excretion of ASP-form leucine plus valine and urinary N:ASP-form leucine plus valine are probably simple and practical methods for the detection of some of the changes 
Table 6. Summary of nitrogen intake, urinary $N$ excretion and the supposed origin of urinary $N$ in the diabetic or dexamethasone-injected rats compared with control rats

(Mean values for each group of rats; values for $\mathrm{N}$ intake, $\mathrm{N}$ excretion, and ASP-form leucine plus valine excretion in the late stage of the experiment were used to calculate the origin of urinary $\mathrm{N}$.

For the hypotheses for calculation of the origin of urinary $\mathrm{N}$, see Discussion)

\begin{tabular}{|c|c|c|c|c|c|c|c|c|c|}
\hline & \multicolumn{2}{|c|}{ Protein-free diet } & \multicolumn{7}{|c|}{$120 \mathrm{~g}$ Casein $/ \mathrm{kg}$ diet } \\
\hline & Control & Diabetic & Control & Diabetic & ADX & $\mathrm{ADX}+\mathrm{Dex}$ & ADX-maize oil & ADX-sham & \\
\hline & Mean & Mean & Mean & Mean & Mean & Mean & Mean & Mean & LSD $^{*}$ \\
\hline Dietary N (mg/d) & 0 & 0 & $279^{\circ}$ & 431 & $135^{\mathrm{a}}$ & $168^{a b}$ & $215^{\mathrm{abe}}$ & $250^{\mathrm{be}}$ & $90-8$ \\
\hline Total urinary $\mathrm{N}(\mathrm{mg} / \mathrm{d})$ & $24 \cdot 8$ & $90 \cdot 1$ & $62 \cdot 8^{\mathrm{a}}$ & $332 \cdot 3$ & $62 \cdot 8^{\text {an }}$ & $203 \cdot 5^{\mathrm{b}}$ & $56 \cdot 4^{\mathrm{a}}$ & $55 \cdot 0^{\mathrm{a}}$ & 57.9 \\
\hline Exogenous $\mathrm{N}$ & 0 & 0 & $6 \cdot 1^{u}$ & $143 \cdot 2$ & $16 \cdot 2^{a}$ & $8 \cdot 1^{\mathrm{a}}$ & $3 \cdot 2^{\mathrm{a}}$ & $2 \cdot 5^{\mathfrak{a}}$ & $26 \cdot 9$ \\
\hline Extra $N$ excretion & $(0) \dagger$ & $42 \cdot 9$ & $(0) \dagger$ & $90 \cdot 0$ & & & & & \\
\hline Endogenous $\mathrm{N}$ & $24 \cdot 8$ & $47 \cdot 2$ & $56 \cdot 7^{\mathrm{a}}$ & $99 \cdot 1$ & $46 \cdot 6^{\mathrm{a}}$ & $1954^{b}$ & $53 \cdot 2^{\mathrm{a}}$ & $52-5^{\mathrm{a}}$ & $73 \cdot 8$ \\
\hline Efficiency of dietary $N(\%)+$ & & & 97.8 & $66 \cdot 8$ & $88 \cdot 0$ & $95 \cdot 2$ & $98 \cdot 5$ & $99 \cdot 0$ & \\
\hline
\end{tabular}

a,b,e Groups with unlike superscript letters were significantly different $(P<0.05$ or less) by Tukey's $Q$ test (Snedecor \& Cochran, 1967a).

ADX, adrenalectomized; ADX + Dex, adrenalectomized and injected with dexamethasone in maize oil.

* Least significant difference at $5 \%$ calculated using Tukey's $Q$ test appropriate only for comparison of treatments within the adrenalectomy experiment (including control or non-ADX group).

$\dagger$ Assumed to be 0 .

+ (Dietary $N$-exogenous $N) \times 100 /$ dietary $N$.

or disorders in body protein metabolism before further critical examinations of the patients suffering from degenerative diseases or of the people under inadequate nutritional conditions.

\section{REFERENCES}

Flaim, K. E., Copenhaver, M. E. \& Jefferson, L. S. (1980). Effects of diabetes on protein synthesis in fast- and slow-twitch rat skeletal muscle. American Journal of Physiology 239, E88-E95.

Garlick, P. J., Preedy, V. R. \& Reeds, P. J. (1985). Regulation of protein turnover in vivo by insulin and amino acids. In Intracelltilar Protein Catabolism, pp. 555564 [E. A. Khairallah, J. S. Bond and J. W. C. Bird, editors] New York: Alan R. Liss.

Manchester, K. L. (1970). Site of hormonal regulation of protein metabolism. In Mammalian Protein Metabolism, vol. 4, pp. 254-262 [H. N. Munro, editor]. New York and London: Academic Press.

Millward, D. J., Garlick, P. J., Nnanyelugo, D. O. \& Waterlow, J. C. (1976). The relative importance of muscle protein synthesis and breakdown in the regulation of muscle mass. Biochemical Journal 156, $185-188$.

Millward, D. J. \& Waterlow, J. C. (1978). Effect of nutrition on protein turnover in skeletal muscle. Federation Proceedings 37, 2283-2290.

Munro, H. N. (1964). General aspects of the regulation of protein metabolism by diet and by hormones. In Mammalian Protein Metabolism, vol. 1, pp. 38 1-481 [H. N. Munro and J. B. Allison, editors]. New York and London: Academic Press.

Nagasawa, T., Kadowaki, M., Noguchi, T. \& Naito, H. (1982). The effect of insulin on myofibrillar protein degradation in normal and streptozotocin-induced diabetic rats measured by the rate of $\mathrm{N}^{7}$-methylhistidine release from perfused hindquarters. Agricultural and Biological Chemistry 46, 3023-3027.

Nishizawa, N., Shimbo, M., Noguchi, T., Hareyama, S. \& Funabiki, R. (1978). Effect of starvation, refeeding and hydrocortisone administration on turnover of myofibrillar proteins estimated by urinary excretion of $\mathrm{N}^{+}$methylhistidine in the rat. Agricultural and Biological Chemistry 42, 2083-2089.

Noguchi, T., Nam, T. J., Kato, H. \& Naito, H. (1988). Further studies on the nutritional factors affecting the urinary excretion of acid-soluble peptides in rats. British Journal of Nutrition 60, 321-337.

Noguchi, T., Okiyama, A., Naito, H., Kaneko, K. \& Koike, G. (1982). Some nutritional and physiological factors affecting the urinary excretion of acid-soluble peptides in rat and women. Agricultural and Biological Chemistry 46, $2821-2828$.

Odedra, B. R., Bates, P. C. \& Millward, D. J. (1983). Time course of the effect of catabolic doses of corticosterone on protein turnover in rat skeletal muscle and liver. Biochemical Journal 214, 617-627.

Odedra, B. R. \& Millward, D. J. (1982). Effect of corticosterone treatment on muscle protein turnover in adrenalectomized rats and diabetic rats maintained on insulin. Biochemical Journal 204, 663-672. 
Pain, V. M., Albertse, E. C. \& Garlick, P. J. (1983). Protein metabolism in skeletal muscle, diaphragm, and heart of diabetic rats. American Journal of Physiology 245, E604-E610.

Pain, V. M. \& Garlick, P. J. (1974). Effect of streptozotocin diabetes and insulin treatment on the rate of protein synthesis in tissues of the rat in vivo. Journal of Biological Chemistry 249, 4501-4514.

Rogers, Q. R. \& Harper, A. E. (1965). Amino acid diets and maximal growth in the rat. Journal of Nutrition 87, 267-273.

Snedecor, G. W. \& Cochran, W. G. (1967a). Factorial experiments. The split-plot or nested design. In Statistical Methods, 6th ed., pp. 369-375. Ames, Iowa: Iowa State University Press.

Snedecor, G. W. \& Cochran, W. G. $(1967 \mathrm{~b})$. Factorial expcriments. The general two-factor experiments. In Statistical Methods, 6th ed., pp. 346-349. Ames, Iowa: Iowa State University Press.

Snedecor, G. W. \& Cochran, W. G. (1967c). One-way classifications. Analysis of variance. Inspection of all differences between pairs of means. In Statistical Methods, 6th ed., pp. 271-273. Ames, Iowa: Iowa State University Press.

Tomas, F. M., Munro, H. N. \& Young, V. R. (1979). Effect of glucocorticoid administration on the rate of muscle protein breakdown in vivo in rats, as measured by urinary excretion of $\mathrm{N}^{7}$-methylhistidine. Biochemical Journal 178, 139-146.

Tomas, F. M., Murray, A. J. \& Jones, L. M. (1984). Modification in glucocorticoid-induced changes in myofibrillar protein turnover in rats by protein and energy deficiency as assessed by urinary excretion of $\mathrm{N}^{\tau}$ methylhistidine. British Journal of Nutrition 51, 323-337.

Waterlow, J. C., Garlick, P. J. \& Millward, D. J. (1978). The effects of nutrition and hormones on protein turnover in muscle. In Protein Turnover in Mammalian Tissues and in the Whole Body, pp. 667-681. Amsterdam. New York and Oxford: North-Holland. 